\title{
Geoscięnces
}

\section{Orange opals from Buriti dos Montes, Piauí: solid inclusions as genetic guides}

http://dx.doi.org/10.1590/0370-44672015680203

\section{Gisele Tavares Marques}

Mestranda do Programa de Pós-Graduação

em Geologia e Geoquímica,

Universidade Federal do Pará - UFPA

Belém - Pará - Brazil

gisageo15@yahoo.com.br

\author{
Marcondes Lima da Costa \\ Professor colaborador, \\ Universidade Federal do Pará - UFPA \\ Belém - Pará - Brazil \\ mlc@ufpa.br
}

\section{Érico Rodrigues Gomes}

Professor do ensino básico, técnico e tecnológico do Instituto Federal de Educação,

Ciência e Tecnologia do Piauí

ericorg@uol.com.br

\section{Opalas laranjas de Buriti dos Montes, Piauí: inclusões sólidas como guias genéticos}

\begin{abstract}
Orange opals from Buriti dos Montes (Piauí, northeastern Brazil) have gemological properties that favor their use as jewelry; these characteristics include their colors, transparency, relatively high stability and hardness. The exotic content of solid inclusions provides greater beauty to the opals of this region. These opals originated from hydrothermal processes and are found mainly as veinlets and veins in the sandstones of the Serra Grande Group, sectioned by diabase dikes and sills of the Sardinha Formation. Solid inclusions, such as bubbles, botryoidal aggregates, dendrites, and nodules, among others, consist mainly of kaolinite, hematite/goethite and quartz and influence the chemical composition of opals. Intense zoning of quartz crystals and high values of $\mathrm{Ba}$ and $\mathrm{Fe}$ suggest that opal deposits were formed in a hydrothermal environment. Diabase dykes could have been responsible for heating the hydrothermal fluids. Sandstones, rich in aqueous solutions, also contributed to the available silica for the saturation of these solutions, and fractures enabled the migration and entrapment of hydrothermal fluids, resulting in the mineralized veins.
\end{abstract}

Keywords: orange opal, solid inclusions, hydrothermal genesis.

\section{Resumo}

As opalas laranjas de Buriti dos Montes (Piauí, nordeste do Brasil) têm propriedades gemológicas que favorecem seu uso como jóias; essas características incluem as cores, transparência, dureza e estabilidade relativamente elevadas. O exótico conteúdo de inclusões sólidas proporciona maior beleza às opalas da região. Essas opalas foram originadas por processos hidrotermais $e$ são encontradas, principalmente, em vênulas e veios nos arenitos do Grupo Serra Grande, seccionados por soleiras e diques de diabásio da Formação Sardinha. Inclusões sólidas, tais como bolhas, agregados botrioidais, dendritos e nódulos, entre outras, consistem, principalmente, de caulinita, hematita/goethita e quartzo e influenciam a composição quimica das opalas. O zoneamento intenso dos cristais de quartzo e os elevados valores de Ba e Fe sugerem que os depósitos de opala foram formados em ambiente hidrotermal. Os diques de diabásio teriam sido responsáveis pelo aquecimento dos fluidos hidrotermais. Os arenitos, ricos em soluções aquosas, também teriam contribuído com a sílica disponível para a saturação dessas soluções e as fraturas permitiram a migração e aprisionamento dos fluidos hidrotermais, resultando nos veios mineralizados.

Palavras-chave: opala laranja, inclusões sólidas, gênese hidrotermal. 


\section{Introduction}

In the Piauí State of northeastern Brazil, Pedro II and Buriti dos Montes counties have the most important opal occurrences of the country. The gemological qualities of these opals are equivalent to the famous Australian opals. According to Gomes (2002), the orange opals from Buriti dos Montes do not exert the same fascination as the precious opals from Pedro II because they do not show a playof-colors. However, this variety has been highly appreciated due to other features,

Localization and access: Buriti dos Montes County is located in the northeastern part of the Piauí State, approximately 230 kilometers $(\mathrm{km})$ east of the capital, Teresina. Access to Buriti dos Montes County from Teresina is facilitated by federal and state highways that intersect the region through Campo Maior and Castelo do Piauí.

Geological context and occurrence: The Piauí opals are hosted in the sedimentary rocks of the Parnaíba Paleozoic Basin, which involves three depositional cycles controlled by global tectonics, as proposed by Góes \& Feijó (1994): the Silurian (Serra Grande Group), Devonian (Canindé Group) and CarboniferousTriassic (Balsas Group) sequences. The Jurassic (Pastos Bons, Corda, Sardinha and Mosquito Formations) and Cretaceous (Grajaú, Codó and Itapecuru Formations, in the north, and Areado Group

\section{Materials and methods}

One hundred forty six opal samples distributed into 20 lots, with an average of approximately 7 pieces each were used. These samples were collected by the geologist Érico Rodrigues Gomes.

X-Ray Powder Diffraction (XRD): XRD was carried out at the Mineral Characterization Laboratory of the Geosciences Institute of Federal University of Pará (IG-UFPA). XRD was used to determine the main mineral phases and crystalline order-disorder degree (crystallinity) of the opals, which were prepared by the powder method.

Inductively Coupled Plasma-Mass Spectrometry (ICP-MS): ICP-MS was conducted at Acme Analytical Laboratories Ltd. to determine the bulk chemical composition of the opals. which are also suitable for use in jewelry, such as their orange hues, transparency, hardness and relatively high stability. The exotic content of solid inclusions provides greater beauty to the orange opals found in this region. These inclusions occur isolated or in various arrangements with millimetric to centimetric size that are intrinsic to Buriti dos Montes opals. Similar solid inclusions have been described in Mexican opals by Koivula et al. (1983), Gübelin \& Koivula (1986a,

and Urucuia Formation, in the south) sequences were considered part of this ba$\sin$ but are directly related to the rupture of Gondwana; therefore, their evolutions are distinct from the Parnaíba Basin. Góes (1995) and Rossetti et al. (2001) suggested the names Alpercatas, Grajaú and Espigão-Mestre for these basins. The Serra Grande Group occurs within the limits of the Parnaíba Basin and presents itself in discordance with the overlying Canindé Group. According to Góes et al. (1990), the Serra Grande Group represents the first marine deposition in the Parnaíba Basin, corresponding to a complete transgressive-regressive cycle, where fluvial-deltaic to shallow marine sediments were deposited and consolidated into Ipu, Tianguá and Jaicós Formations. In general, continental sandstones and conglomerates with possible glacial influence (Ipu Formation) are present in 1986b, 2005), Smith (1990) and Spencer et al. (1992); Mexican opals are also well known in the international gemological market. As shown by Gomes (2002), Gomes \& Costa (2001), Marques (2011) and Marques et al. (2012), Piauí opals originated from hydrothermal processes. In this context, this paper discusses the morphology, mineralogical and chemical composition of solid inclusions, their interaction with the orange opals and their genetic significance.

gradual contacts with sandstones and marine shales (Tianguá Formation) that are overlapped by sandstones and fluvial conglomerates (Jaicós Formation). The Cretaceous basic intrusive magmatism occurs in the form of sills and dykes that constitute the Sardinha Formation and cross cut the Parnaíba Basin (Góes, 1995), including its base, where the rocks of Serra Grande Group that host the studied opals are found. These orange opals are found mainly as veins and veinlets, filling the fractures in Serra Grande Group sandstones. They also occur in cementing breccias in the contact zone between host rocks and mafic dykes. These primary deposits formed the source for the colluvial and paleochannel deposits. Locally, there are veins of quartz associated with opals with goethite dispersed between quartz crystals and opals (Gomes \& Costa, 2001).

The opals and their inclusions were characterized by their morphology, micromorphology, and mineralogical and chemical compositions using the following analytical techniques:

We used an X-ray diffractometer (model X'Pert Pro MPD (PW 3040/60) PANalytical) with a PW3050/60 ( $\theta-\theta)$ goniometer and an X-ray tube ceramic with a $\mathrm{Cu}$ anode $(\mathrm{K \alpha} 1=1.540598 \AA)$ model PW3373/00, long fine focus, $\mathrm{Ni} K \beta$ filter, $\mathrm{X}^{\prime}$ Celerator Real Time Multiple Scanning (RTMS) detector in scanning mode with an active length of

The samples were previously powdered into aliquots of $200 \mathrm{mg}$, melted with lithium metaborate and tetraborate, and then dissolved with nitric acid.

The major C, S, and trace ele-
Optical stereomicroscopy: All samples were observed with a Zeiss stereomicroscope (model Stemi 2000-C), described according to their macroscopic features and photographed.

$2.122^{\circ}$. Scans were conducted from $5^{\circ}$ to $75^{\circ} 2 \theta$ with a voltage of $40 \mathrm{kV}$, a 30 $\mathrm{mA}$ current, $\mathrm{a} 0.02^{\circ}$ step in $2 \theta$ and $10 \mathrm{~s} /$ step, an automatic and $4^{\circ}$ anti-scattering slit, a $10-\mathrm{mm}$ mask, and a spinning motion of sample with 1 rps. The data were processed and interpreted using an X'Pert Data Collector and X'Pert High Score software, both from PANalytical.

ments, including rare earth elements (REE), were determined.

The loss on ignition (LOI) is given by the difference in weight after calcination at $1000^{\circ} \mathrm{C}$. 
Scanning Electron Microscopy (SEM/EDS/CL): Fragments and polished thin sections of opals, emphasizing their inclusions, were used for the morphological and mineralogical study using secondary electron (SE) images and energy dispersive spectrometry (EDS) semi-quantitative chemical analysis. All fragments of samples were fixed on stubs with carbon double-sided tape and coated with gold for 2 minutes. The

\section{Opal Structure}

The opals from Buriti dos Montes are semitransparent to translucent and have a wide range of hues, from light yellow to brownish red. In the SEM images, it is possible to see that the interstices between silica spheres forming the opal were partially filled by opal ce-

Figure 1

A, B - Subspherulitic arrangement of the orange opals, whose cementation generates a massive aspect. Secondary electron images obtained using SEM. Scale bar $=1.5 \mu \mathrm{m}$.

\section{Solid Inclusions Morphology}

The different types of solid inclusions in the studied opals were identified and classified according to morphology using criteria such as shape, color, size and texture as well as the three-dimensional arrangement produced within the opals.

The inclusions, named bubbles, correspond to rounded cavities with diameters between 5 and $20 \mathrm{~mm}$ and are cream-white or brownish according to the filling, usually of host sandstones. Some bubbles have a white film on the

\footnotetext{
Figure 2

Opals from Buriti dos Montes with the main solid inclusions and associated features.

A - bubble with tension fracture, B - white opal bubble with Fe oxy-hydroxides in the center, C - botryoidal-columnar inclusion with tension fractures, D - dendrites,

E - lamellar inclusions with botryoidal terminations, $F$ - helicitic inclusions with dry fractures, $G$ - sealed fractures in red opal, $\mathrm{H}$ - red patch in orange opal.
}

polished thin sections were also used to obtain backscattered (BSE) and cathodoluminescence (CL) images, in addition to EDS analysis. These thin sections were coated with gold for 2 minutes for EDS analysis and 30 seconds for CL images, with a coating thickness of $15 \mathrm{~nm}$ and $3 \mathrm{~nm}$, respectively. A LEO ZEISS SEM (model 1430) with a SiriusGresham EDS detector and a Gatan Mono-CL belonging to the Laboratory

ment, masking the typical subspherulitic aspect, giving rise to an almost massive feature (Figure 1A, B). The sphere diameters range from 150 to $500 \mathrm{~nm}$. Irregular spheres and compact arrangements do not allow for the production of a play-of-colors, an effect that manifests itself only when the spheres are perfect,
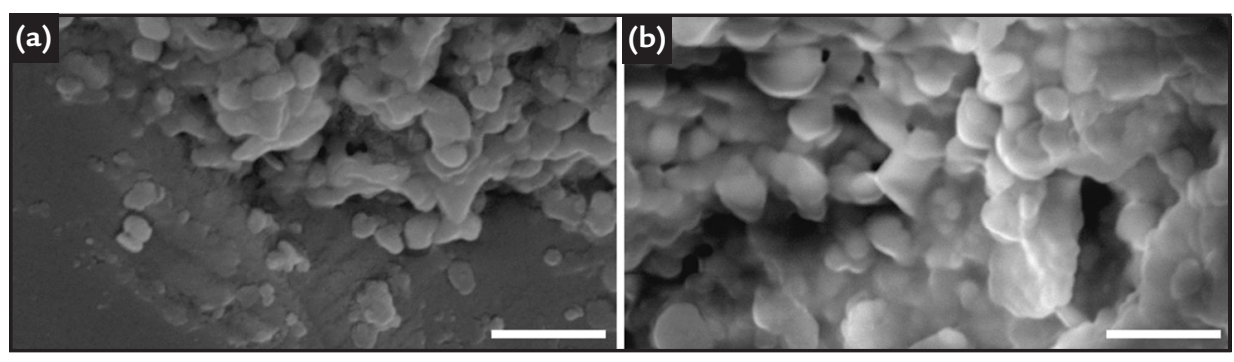

inner wall of the cavity, while others are completely empty, which most likely indicates already-released gas content. There are bubbles surrounded by tension fractures (Figure 2A) with an external appearance of microconcretions and filled with opaline silica (Figure 2B). The botryoidal inclusions are sandy aggregates of the host rock, with a botryoidal aspect and a general tendency towards rounding. Their color varies from white to cream and brown to reddish tones. The spatial arrangement of these inclu- of Scanning Electron Microscopy of the UFPA were used.

Operating conditions for the SE and BSE images and the EDS analysis were as follows: beam current $=90$ $\mu \mathrm{a}$, accelerating voltage $=20 \mathrm{kV}$, work distance $=15 \mathrm{~mm}$, scanning time $=30$ s with 3000 to 4000 cycles per second (c/s) for each analysis. The conditions for the CL images were the same but with work distance $=13 \mathrm{~mm}$.

uniform in size and have a regular packing without any interstices filling (Wollaert et al., 1990). However, these opals have good transparency, which may be related to the size of the spaces between the spheres. According to Schwartz (1984), small interstices provide greater transparency to opals.
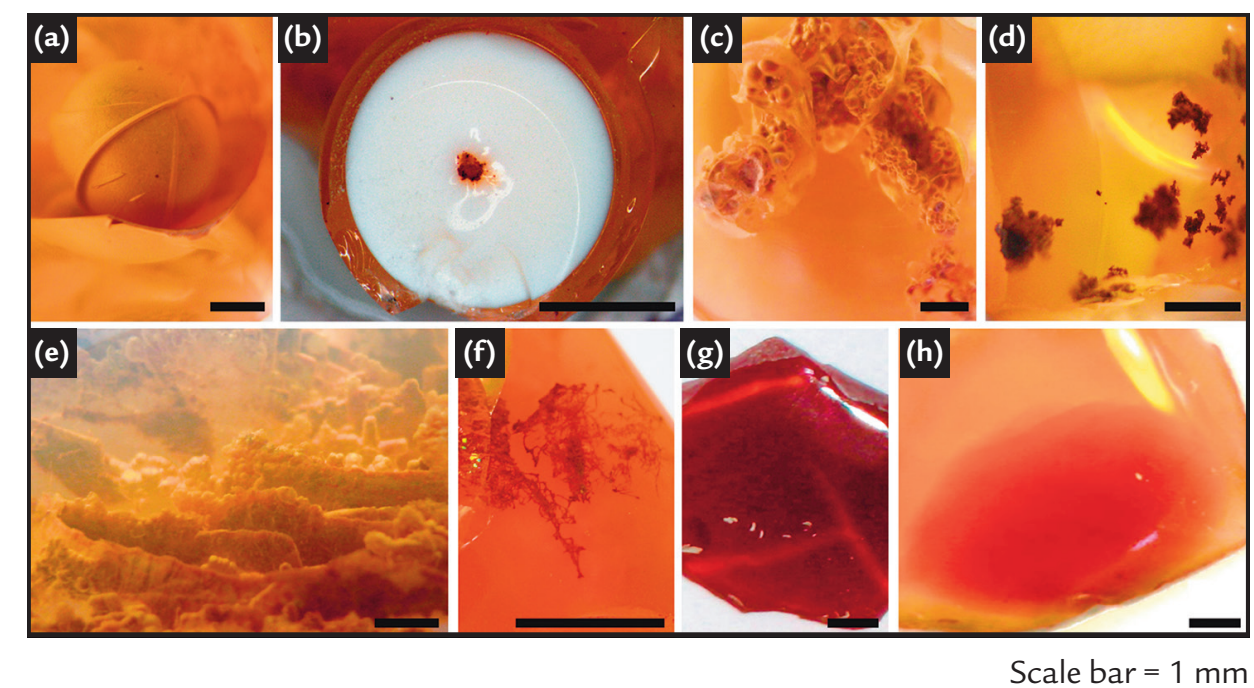

sions within the opals allows for characterizing different morphologies, such as coral reefs, stalactites, stalagmites and columns (Figure 2C). Dendritic inclusions (Figure 2D), with a typical arborescent aspect, are dark, usually brown, and are associated with botryoidal inclusions, bubbles and fractures.

The tabular or lamellar inclusions (Figure 2E) are groups of parallel lamellae or platelets of sandy material. Microcrystals, isolated or grouped, are euhedral and well formed. Microcrystals 
of quartz inclusions in these opals are frequent. Nodules, composed of materials from the host rocks, represent sandy fragments that were not completely dissolved during the migration of hydrothermal fluids. The helicitic inclusions or cobwebs (Figure 2F) are formed by brown, irregular tiny needles, similar to strands of hair, together constituting an arrangement similar to a cobweb. The tubes are cylindrical and elongated

\section{Mineralogical Caracterization}

The mineralogical analysis by XRD revealed different order-disorder degrees in orange opals, from amorphous opals (opal-A) to cristobalite-tridymite opals (opal-CT). Samples GB 7-28, GB 8-37 and GB 6-2 are typical of opal-A, whose diffraction patterns show a main peak with $\mathrm{d}=4.11 \AA$ (4.10/4.12), broad and high background, and another incipient in $\mathrm{d}=2.50 / 2.51 \AA$. The high background and low resolution of the peak $d=4.32 \AA$, sometimes almost imperceptible, suggest low-order crystalline, approaching an amorphous state. Samples GB 2-14 and GB 9-6 are typically opal-CT, characterized by interplane distances $\mathrm{d}=4.10 \AA$ (4.11), 4.31 $\AA$ (4.32/4.33), $2.50 \AA, 2.05$ $\AA$ and $1.63 \AA$. Among the terms defined as amorphous and cristobalite-tridymite, there are intermediate stages of orderdisorder crystalline, as in the GB 1-24, GB 5-5, GB 4-5, GB 3-20 and GB 10 samples channels, sometimes curved, with millimetric diameter, which may be empty or partially or completely filled with sandy material. The filling gives reddish or whitish colors to the tubes.

Some features, such as flow structures (striations that represent the probable migration of fluids through fractured host sandstone) and fractures, occur in isolation or in association with botryoidal inclusions and bubbles. There

(Figure 3A, B). The presence of kaolinite in the solid inclusions is indicated by reflections $\mathrm{d}=7.17 \AA(7.18 / 7.19)$ and 3.58 $\AA$. The interplane spacings $d=3.34 \AA$ (3.35), $1.54 \AA$ and $1.44 \AA$ refer to quartz microcrystal inclusions in the opals. These quartz microcrystals as well as botryoidal and lamellar inclusions, nodules and tubes formed predominantly by kaolinite have been confirmed by EDS analysis.

In addition to these minerals, hematite and/or goethite were also found in the darker portions of the botryoidal, dendritic and helicitic inclusions as well as in the nodules and in the center of a bubble formed by white opal within yellow opal. Opaline pseudomorphs of gypsum or barite (Figure 4A, B) were found locally, filling small cavities in opals. EDS analysis indicated only $\mathrm{Si}$ and $\mathrm{O}$, showing that these inclusions were completely replaced by the opaline silica, preserving, however,

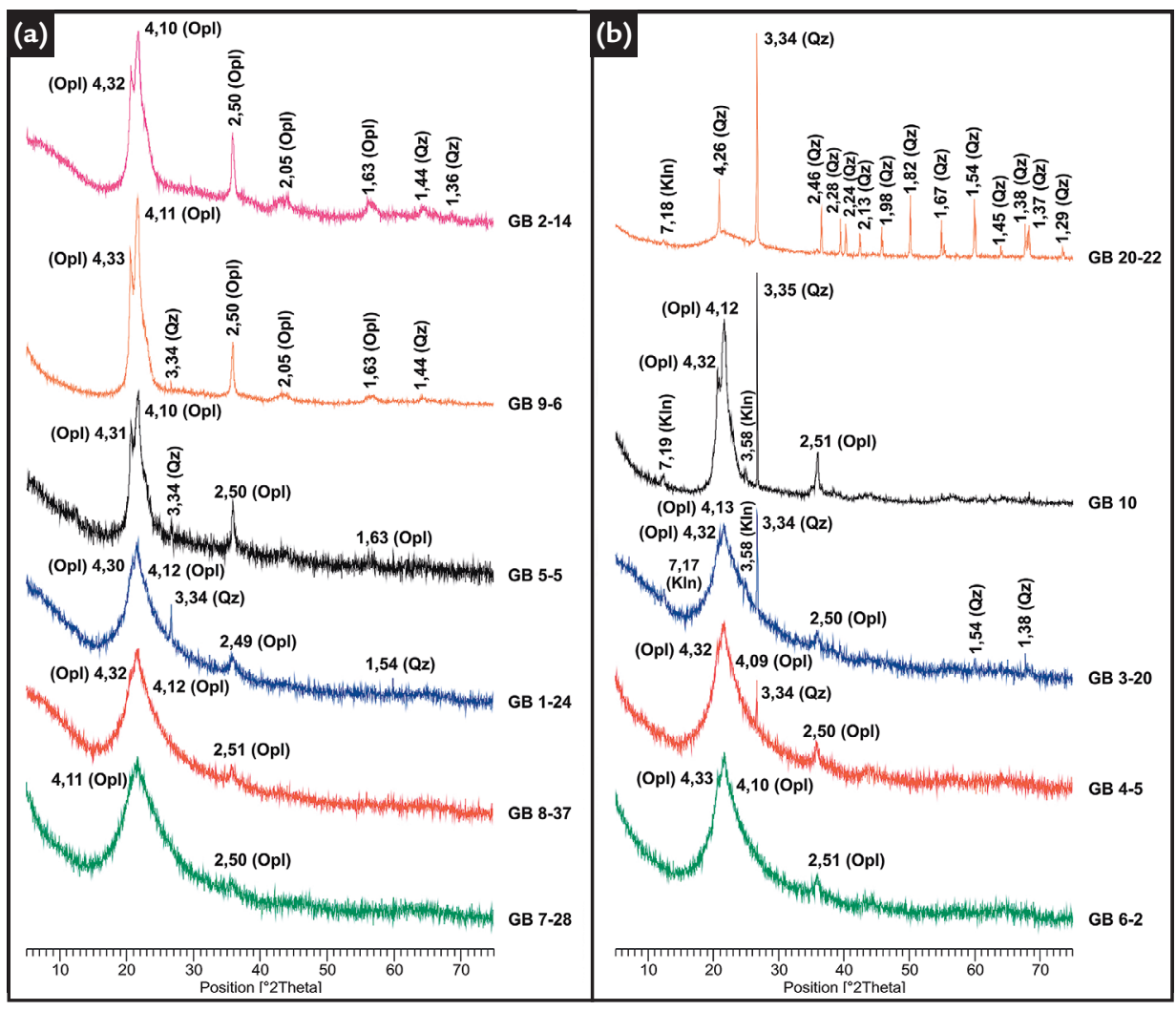

are sealed fractures (Figure 2G - totally filled by opal), dry fractures (unfilled fractures), tension fractures (semicircular fractures that surround other inclusions), superficial fractures (external fractures, non-penetrative) and cracking fractures (group of interconnected fractures that delimit small polygons with penetrative character). Patches and color zones (Figure $2 \mathrm{H}$ ), also frequent, are portions of opal with variations of the main color.

the shape of the crystals. Hyaline quartz also occurs in small druses and accompanying veins of opal. When imaged by CL using SEM, these crystals reveal a pattern of concentric zoning perpendicular to the c-axis, showing various intensities of luminescence. This feature is diagnostic of hydrothermal origin (Rusk et al., 2006; 2008) and contrasts strongly with the extremely homogeneous texture, i.e., without zoning, exhibited by grains of detrital quartz of the sandstones that host the mineralization. In CL images, venules of hydrothermal quartz overgrown on detrital quartz were observed (Figure 5A, $\mathrm{B})$, indicating that fluids migrated through the interstices of the grains into the sandstones. The thickness of hydrothermal quartz veinlets gradually increases toward the ore veins, until the detrital grains are completely consumed, leaving neoformed euhedral quartz crystals (Figure 5C).
Figure 3

A, B - X-ray diffraction diagrams showing the different order-disorder degrees of the studied opals, with variation between opal-A and CT, and intermediate levels, from the base upwards. Kln - kaolinite, Opl - opal, Qz - quartz (abbreviations of mineral names based on Whitney \& Evans, 2010). 
Figure 4

A, B - Pseudomorphs of gypsum or barite included in orange opals. Secondary electron images obtained using SEM.
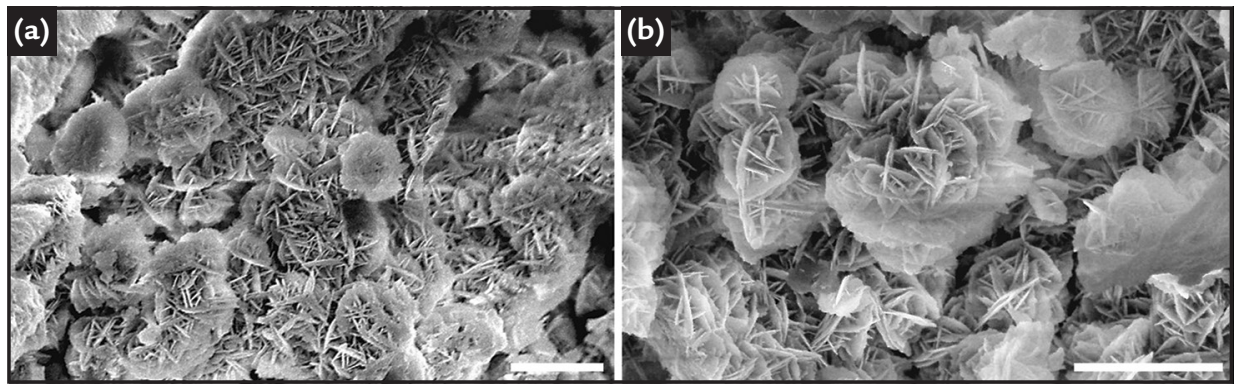

Scale bar $=5 \mu \mathrm{m}$.

Figure 5

A, B - Detrital quartz grains (Qz1) of sandstones that host the opal mineralization with hydrothermal quartz overgrowth

(Qz2). C - Euhedral quartz crystal (Qz3) with internal concentric zoning. Cathodoluminescence images obtained using SEM.

\section{Chemical Composition}

The opals from Buriti dos Montes are composed mainly of $\mathrm{SiO}_{2}(90.14 \%$ on average) and $8.03 \%$ water (based on LOI), $1.32 \% \mathrm{Al}_{2} \mathrm{O}_{3}$ and $0.2 \% \mathrm{Fe}_{2} \mathrm{O}_{3}$. The $\mathrm{SiO}_{2}$ contents correlate negatively with $\mathrm{Al}_{2} \mathrm{O}_{3}$ and $\mathrm{Fe}_{2} \mathrm{O}_{3}$, most likely due to the mineral inclusions, such as kaolinite and hematite. Part of the silica-contents is also found as quartz inclusions. Al can also be a potential Si replacement in the opal structures. Among the analyzed
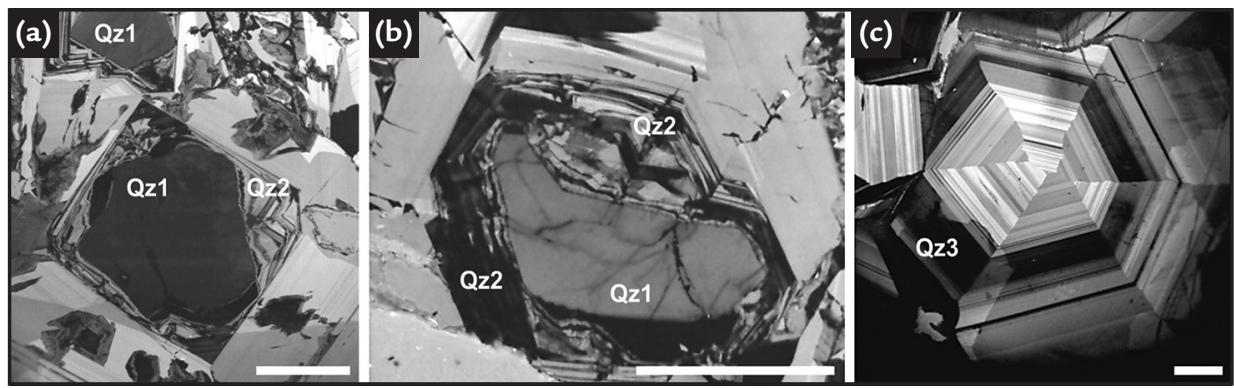

Scale bar $=100 \mu \mathrm{m}$. Qz - quartz (abbreviations of mineral names based on Whitney \& Evans, 2010).

trace elements, only the high values of $\mathrm{Ba}$ are highlighted, ranging between 195 and 1373 parts per million (ppm), with an average of $808 \mathrm{ppm}$ (Figure 6A). Other trace-element contents are very close to the detection limits. Gomes (2002) emphasizes that barite veins are common in the sandstones that host opals. The GB 4 sample, which is richer in $\mathrm{Al}_{2} \mathrm{O}_{3}$ and $\mathrm{Fe}_{2} \mathrm{O}_{3}$, displays the highest contents of REEs (Figure 6B) and trace elements, most likely due to an association with the solid inclusions of hematite and kaolinite. From EDS analysis, it was possible to identify higher contents of Fe in patches and dark colored zones than in the opal matrix. Similarly, reaction borders surrounding helicitic and dendritic inclusions have higher contents of Fe, with an average of 4500 ppm compared with the surrounding opal with an average of 1700 ppm of Fe.

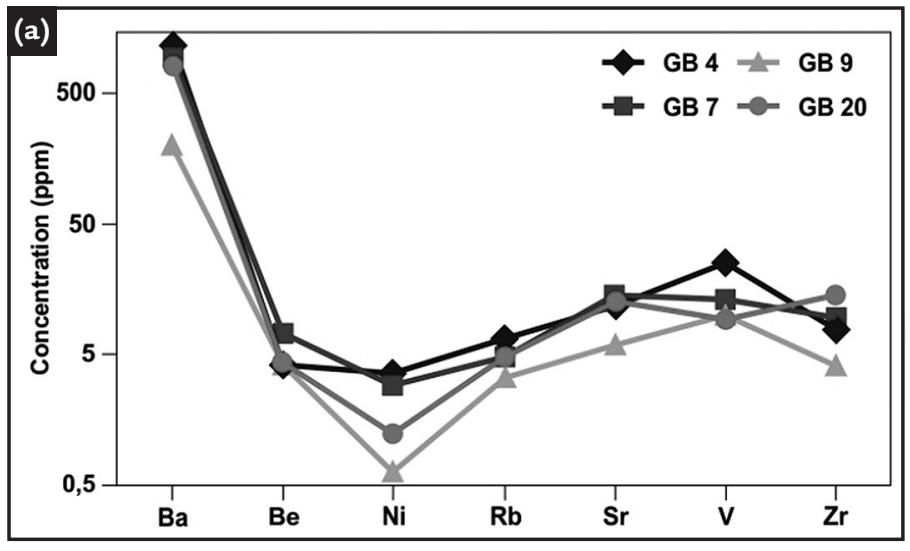

Figure 6

A - Multi-elements diagram with the distribution of trace elements in the opals.

Trace element concentrations (ppm) are relatively higher in sample GB 4.

B - Diagram showing the distribution of REE in these opals and considerable enrichment in sample GB 4. The contents were normalized by chondrite of Taylor \& McLennan (1985).

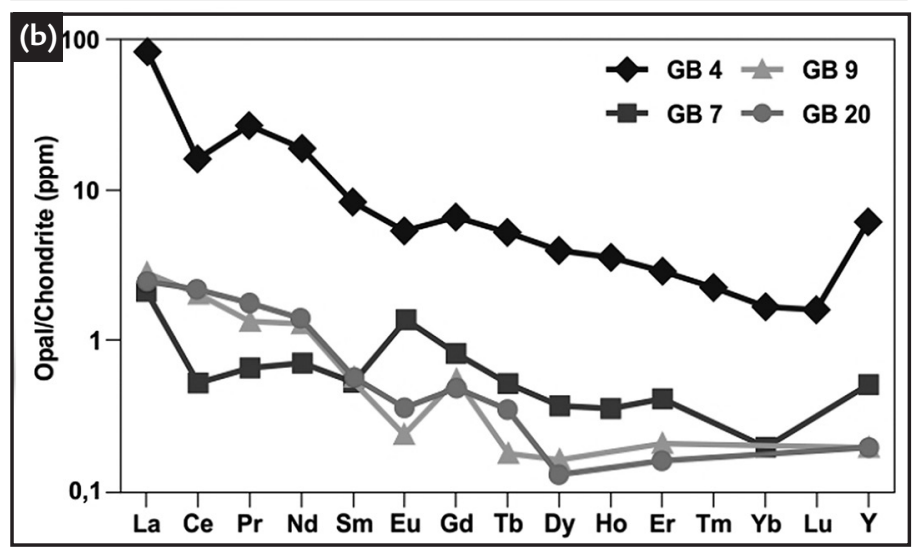




\section{Discussion and conclusions}

The vast content of solid inclusions, their arrangements, contact relationships, mineralogy and chemical composition reinforce the hydrothermal genesis of orange opals from Buriti dos Montes as suggested by Gomes (2002), and discussed by Marques (2011). Most inclusions are formed by materials from the host rocks or simply from particles that were involved by fluids during their migration through the fractures in these sandstones. The hydrothermal fluid flow is evident in flow structures present in the opals and on features representing partial dissolution of some inclusions (e.g., the reaction borders around the helicitic and dendritic inclusions). Other features, such as sealed fractures, patches and zoning of colors, refer to late fluid flow and partial dissolution of hematitic plasma particles. The color zoning was created by neoformation of Fe oxy-hydroxides such as hematite and goethite within the opals. The possible existence of micro and nano-inclusions, rich in these minerals can also contribute to this effect (Fritsch et al., 1999; 2002; 2006; Steffen, 2000; Gaillou et al., 2008). The lamellar inclusions reveal a structure that can originate from the deformation of sandstones assimilated by fluids, considering that the mineralized area is under the influence of the Transbrasiliano Lineament. The opals from Buriti dos Montes are marked by high contents of $\mathrm{Ba}$ and $\mathrm{Fe}$. Ba may possibly constitute inclusions of barite, a common mineral in rocks of the region. Fe occurs as oxyhydroxides in solid inclusions, which give the distinct orange color to these opals. The presence of barite, hematite and kaolinite also reinforces the context of a hydrothermal environment for the origin of these opals. This hydrothermal genesis is also confirmed by the presence of hyaline quartz with intense zoning in CL, in lateral contact with opal in the veins, and as microcrystals included in the opals. This hypothesis is corroborated by the morphology of the inclusions, by the mineral assemblage characterized by hematite, barite and kaolinite, and by the simultaneous occurrence of inclusions and veins of typically hydrothermal quartz.

This hydrothermal environment was most likely conditioned by the diabases of the Sardinha Formation, which acted as the heat source responsible for heating the aqueous solutions present in the sandstones of the Serra Grande Group. These sandstones also contributed to most of the solubilized silica necessary for the saturation of the solution, while extensive and numerous fractures were indispensable for trapping these hydrothermal solutions, thereby hosting the mineralized veins.

\section{References}

FRITSCH, E., RONDEAU, B., OSTROOUMOV, M., LASNIER, B., MARIE, A-M., BARRAULT, A., WERY, J., CONNOUÉ, J., LEFRANT, S. Découvertes récentes sur l'opale. Revue de Gemmologie a.f.g, v. 138/139, p. 34-40, 1999.

FRITSCH, E., OSTROOUMOV, M., RONDEAU, B., BARREAU, A., ALBERTINI, D., MARIE, A-M., LASNIER, B., WERY, J. Mexican gem opal: nano- and micro-structure, origin of color and comparison with other common opals of gemological significance. The Australian Gemmologist, v. 21, p. 230-233, 2002.

FRITSCH, E., GAILLOU, E., RONDEAU, B., BARREAU, A., ALBERTINI, D., OSTROUMOV, M. The nanostructure of fire opal. Journal of Non-Crystalline Solids, v. 352, p. 3957-3960, 2006.

GAILLOU, E., DELAUNAY, A., RONDEAU, B., BOUHNIK-LE-COZ, M., FRITSCH, E., CORNEN, G., MONNIER, C. The geochemistry of gem opals as evidence of their origin. Ore Geology Reviews, v. 34, p. 113-126, 2008.

GÓES, A. M. A Formação Poti (Carbonífero Superior) da Bacia do Parnaíba. São Paulo: Instituto de Geociências, Universidade de São Paulo, 1995. 171 p. (Tese de Doutorado).

GÓES, A. M. O., FEIJÓ, F. J. Bacia do Parnaíba. Boletim de Geociências da Petrobras, v. 8, n. 1, p. 57-67, 1994.

GÓES, A. M. O., SOUZA, J. M. P., TEIXEIRA, L. B. Estágio exploratório e perspectivas petrolíferas da Bacia do Parnaíba. Bol. Téc. da Petrobras, v. 4, n. 1, p. 56-64, 1990.

GOMES, E. R. Mineralogia e gemologia da opala laranja de Buriti dos Montes (Piauí, Brasil). Belém: Centro de Geociências, Universidade Federal do Pará, 2002. 89p. (Dissertação de Mestrado).

GOMES, E. R., COSTA, M. L. Inclusões sólidas na opala laranja de Buriti dos Montes, Piauí. In: SIMP. GEOL. NORDESTE, 19, 2001. Natal. Anais... Natal: SBG/ Nordeste, 2001. p. 214.

GÜBELIN, E., KOIVULA, J. I. Inclusions in opal. Journal of Gemmology, v. 20, p. 139-144, 1986a.

GÜBELIN, E., KOIVULA, J. I. Photoatlas of inclusions in gemstones. Zurich: ABC Edition, 1986b. 532p.

GÜBELIN, E., KOIVULA, J. Photoatlas of inclusions in gemstones. Basel: Opinio Publishers, 2005. v. 2. 829p.

KOIVULA, J. I., FRYER, C., KELLER, P. C. Opal from Querétaro, Mexico: Occur- 
rence and inclusions. Gems \& Gemology, v. 19-2, p. 87-96, 1983.

MARQUES, G. T. Inclusões sólidas em opalas laranja de Buriti dos Montes (PiauíBrasil): morfologia, mineralogia e composição química. Universidade Federal do Pará, 2011. 75p. (Trabalho de Conclusão de Curso, Graduação em Geologia).

MARQUES, G. T., COSTA, M. L., GOMES, E. R. As fascinantes inclusões sólidas das opalas laranja de Buriti dos Montes (PI). Diamond News, v. 37, p. 45-52, 2012.

ROSSETTI, D. F. Arquitetura deposicional da bacia de São Luís-Grajaú, Meio-Norte do Brasil. In: ROSSETTI, D. F., GÓES, A. M., TRUCKENBRODT, W. (eds.). O Cretáceo na Bacia de São Luís-Grajaú. Belém: Editora do Museu Paraense Emílio Goeldi, 2001. 246p. cap. 3, 31-46.

RUSK, B., REED, M., DILLES, J., KENT, A. Intensity of quartz cathodoluminescence and trace element content of quartz from the porphyry copper deposit in Butte, Montana. American Mineralogist, v. 91, p. 1300-1312, 2006.

RUSK, B. G., LOWERS, H. A., REED, M. H. Trace elements in hydrothermal quartz: relationships to cathodoluminescence textures and insights into vein formation. Geology, v. 36-7, p. 547-550, 2008.

SCHWARTZ, D. Gemas policristalinas e amorfas. REM - Revista da Escola de Minas, v. 27, p. 34-43, 1984.

SMITH, C. P. Opal with an unusual inclusion. Lab Notes. Gems \& Gemology, v. 26, p. 222, 1990.

SPENCER, R. J., LEVINSON, A. A., KOIVULA, J. I. Opal from Querétaro, Mexico: Fluid inclusion study. Gems \& Gemology, v. 28-1, p. 28-34, 1992.

STEFFEN, G. Farbe und lumineszenz von mineralien. Stuttgart: Ed. Enke, 2000. $150 \mathrm{p}$.

TAYLOR, S. R., MCLENNAN, S. M. The continental crust: its composition and evolution. Oxford: Blackwell Scientific Publication, 1985. 312p.

WHITNEY, D., EVANS, B. W. Abbreviations for names of rock-forming minerals. American Mineralogist, v. 95, p. 185-187, 2010.

WOLLAERT, E., VOCHTEN, R., LANDUYT, J. V. Characterization of gem opal and inferior qualities by means of electronmicroscopy. Zeitschrift der Deutschen Gemmologischen Gesellschaft, v. 39, p. 211-223, 1990.

Received: 15 July 2013 - Accepted: 23 October 2014. 